\title{
Hydrologic Modeling of the Bouregreg Watershed (Morocco) Using GIS and SWAT Model
}

\author{
Abdelhamid Fadil ${ }^{1}$, Hassan Rhinane ${ }^{1}$, Abdelhadi Kaoukaya ${ }^{1}$, \\ Youness Kharchaf ${ }^{1}$, Omar Alami Bachir ${ }^{2}$ \\ ${ }^{1}$ Geosciences Laboratory, Faculty of Sciences-Ain Chock, Hassan II Univertsity, Casablanca, Morocco \\ ${ }^{2}$ Hassania School of Public Works, Casablanca, Morocco \\ E-mail:\{a_fadi, alami_bachir\}@yahoo.com, \{h.rhinane, khirchoff2001\}@gmail.com, \\ a.kaoukaya@fsac.ac.ma \\ Received August 6, 2011; revised September 10, 2011; accepted September 22, 2011
}

\begin{abstract}
The study of water resources at watershed scale is widely adopted as approach to manage, assess and simulate these important natural resources. The development of remote sensing and GIS techniques has allowed the use of spatially and physically based hydrologic models to simulate as simply and realistically as possible the functioning of watershed systems. Indeed, the major constraint that has hindered the expansion use of these tools was the unavailability or scarcity of data especially in the developing countries. In this context, the objective of this study is to model the hydrology in the Bouregreg basin, located at the north-central of Morocco, using the Soil and Water Assessment Tool (SWAT) in order to understand and determine the different watershed hydrological processes. Thus, it aims to simulate the stream flow, establish the water balance and estimate the monthly volume inflow to SMBA dam situated at the basin outlet. The ArcSWAT interface implemented in the ArcGIS software was used to delineate the basin and its sub-components, combine the data layers and edit the model database. The model parameters were analyzed, ranked and adjusted for hydrologic modeling purposes using daily temporal data series. They were calibrated using an auto-calibration method based on a Shuffled Complex Evolution Algorithm from 1989 to 1997 and validated from 1998 to 2005. Based on statistical indicators, the evaluation indicates that SWAT model had a good performance for both calibration and validation periods in Bouregreg Watershed. In fact, the model showed a good correlation between the observed and simulated monthly average river discharge with $R^{2}$ and Nash coefficient of about 0.8 . The water balance components were correctly estimated and the SMBA dam inflow was successfully reproduced with $R^{2}$ of 0.9 . These results revealed that if properly calibrated, SWAT model can be used efficiently in semi-arid regions to support water management policies.
\end{abstract}

Keywords: Hydrologic Modeling, Water Balance, Calibration, Bouregreg Watershed, GIS, SWAT, Arcswat

\section{Introduction}

The water is the most important natural resource especially in the arid or semi-arid zones that face high population growth, scarcity of freshwater, irregularity of rainfall, excessive land use change and increasing vulnerability to risks such of drought, desertification and pollution. Thus, the availability and the sustainable use of this resource become the core of the local and national strategies and politics in these regions.

Managing water resources is mostly required at watershed scale [1] given that is the basic hydrologic unit where can be studied the heterogeneity and complexity of processes and interactions linking land surface, climatic factors and human activities. This adopted approach for assessing water quantity and quality was then expressed as various hydrologic models and tools that try to simulate and predict the watershed response at different spatial and time scales.

Many models were developed for watershed hydrology [2] but the availability of temporally and spatially data was the main constraint hindering the implementation of these models especially in developing countries. However, the development of remote sensing techniques and Geographic Information System (GIS) capabilities 
has encouraged and improved the expansion use of these models worldwide. In fact, Abbaspour confirms that the big evolution in watershed modeling will be made as a result of advances in remote sensing data availability [3].

The objective of modeling Bouregreg watershed, located in north-central of Morocco, is to set up and calibrate the adapted model in order to simulate the functioning of the entire basin and therefore predict its response to phenomena and risks it confronts such as erosion, inundations, drought, pollution, etc. Specifically, the purpose is to estimate the volume inflow to the dam of Sidi Mohamed Ben Abdellah (SMBA) located at the outlet of the Bouregreg watershed in order to develop an efficient decision framework to facilitate, plan and assess the management of this important reservoir. Indeed, SMBA dam has a crucial role because it is the source of freshwater of about 6 millions of people living in the axe between Rabat (administrative capital) and Casablanca (economical capital).

The soil and water assessment tool (SWAT) was chosen for this case study because it includes many useful components and functions for simulating the water balance and the other watershed processes such as water quality, climate change, crop growth, and land management practices. In addition, his efficiency and reliability was confirmed in several areas around the world and it was the opportunity to test its performance in Moroccan basins.

SWAT model was tested and used in many regions of Africa especially in the West Africa [4-6] but few studies were conducted in the North Africa. In Morocco, SWAT was never tested or used in large scale basins. The only referenced study using this model is the one conducted in small basin of Rheraya $\left(225 \mathrm{~km}^{2}\right)$ located in southcentral of Morocco to understand and evaluate the hydrological processes in a mountain environment by application of SWAT [7].

Therefore, this study aims to test and evaluate the usefulness and the performance of SWAT to model the hydrological functioning of large scale Moroccan basins through the application of this tool to Bouregreg basin.

\section{Materials and Methods}

\subsection{Description of the Study Area}

Bouregreg Watershed is located at the north-central of Morocco near to Rabat (Figure 1). The outlet of the study area is the SMBA dam situated at $15 \mathrm{~km}$ from Atlantic Ocean. The watershed covers an area of $9570 \mathrm{~km}^{2}$ with an elevation ranging from $46 \mathrm{~m}$ (SMBA outlet) to $1630 \mathrm{~m}$ at the southeast mountains. The main rivers

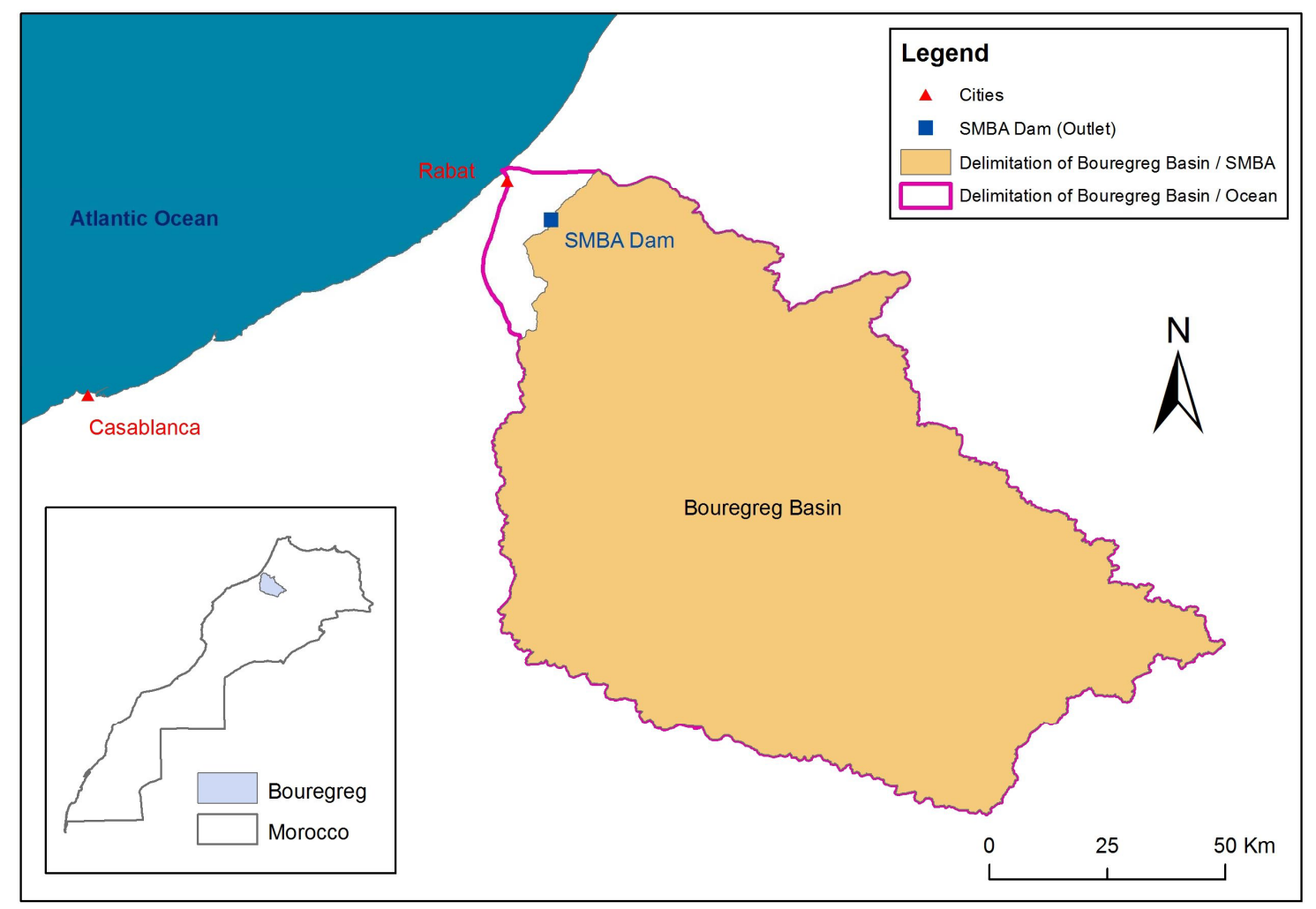

Figure 1. Map situation of Bouregreg watershed. 
are Bouregreg River (125 km) and Grou River (260 km). The climate of the region is semiarid with average yearly precipitations of $400 \mathrm{~mm}$ and annual air temperature varying between $11^{\circ} \mathrm{C}$ for minimum temperatures and $22^{\circ} \mathrm{C}$ for maximum temperatures. The average volume inflow to SMBA dam is estimated at $600 \mathrm{Mm}^{3} /$ year.

\subsection{Description of SWAT Model}

The Soil and Water Assessment Tool (SWAT) is an agro-hydrological watershed scale model developed by Agricultural Research Services of United States Department of Agriculture. It is a physically based and semidistributed model that operates continuously on a daily time step [8].

SWAT allows simulating the major watershed processes as hydrology, sedimentation, nutrients transfer, crop growth, environment and climate change. The aim is to depict the physical functioning of these different components and their interactions as simply and realistically as possible through conceptual equations and using available input data so that it can be useful in routine planning and decision making of large catchments management [9].

One of the main goals of SWAT model is to predict the impact of land management practices on water quantity and quality over long periods of time for large complex watersheds that have varying soils, land use and management practices [10].

The hydrologic cycle is simulated by SWAT model based on the following water balance equation.

$$
S W_{t}=S W_{0}+\sum_{i=1}^{t}\left(R_{\text {day }}-Q_{\text {surf }}-E_{a}-w_{\text {seep }}-Q_{g w}\right)_{i}
$$

where:

- $t$ is the time in days

- $S W_{t}$ is the final soil water content (mm)

- $S W_{0}$ is the initial soil water content (mm)

- $R_{\text {day }}$ is amount of precipitation on day $i(\mathrm{~mm})$

- $Q_{\text {surf }}$ is the amount of surface runoff on day $i(\mathrm{~mm})$
- $E_{a}$ is the amount of evapotranspiration on day $i$ (mm)

- $w_{\text {seep }}$ is the amount of water entering the vadose zone from the soil profile on day $i(\mathrm{~mm})$

- $Q_{g w}$ is the amount of return flow on day $i(\mathrm{~mm})$.

SWAT requires many sets of spatial and temporal input data. As semi-distributed model, SWAT has to process, combine and analyze spatially these data using GIS tools. Therefore, to facilitate the use of the model, it was coupled with two GIS software as free additional extensions: ArcSWAT for ArcGIS and MWSWAT for MapWindow.

\subsection{Creation of Database}

In this study, we had used the ArcSWAT graphical user interface to manipulate and execute the major functions of SWAT model from the ArcGIS tool.

The first step in using SWAT model is to delineate the studied watershed and then divide it into multiple subbasins based on Digital Elevation Model (DEM) and the outlets generated by the intersection of reaches or those specified by the user. Thereafter, each sub-basin is subdivided into homogeneous areas called hydrologic response units (HRUs) that GIS derives from the overlaying of slope, land use and soil layers. Figure 2 gives a global view of SWAT model components including the spatial and GIS parts. The basic spatial data needed for the ArcSWAT interface are DEM, soil type and land use. The temporal data required by the model to establish the water balance (Equation 1) include weather and river discharge data.

The big issue that encounters the application of such hydrologic model in developing countries is the scarcity or unavailability of required data.

In order to overcome this obstacle, we had used in this study a hybrid method combining local and in-situ data gathered from local agencies or administrations and global data got from multiple organizations or global

\begin{tabular}{|c|c|c|c|c|}
\hline Input Data & GIS Processing & Configuring input files & Model Run & Reading output \\
\hline DEM & Watershed Delineation & Writing SWAT Input & Model Run & Reading reports \\
\hline Land use & Sub-basins Delineation & Editing SWAT & Sensitivity Analysis & \multirow[t]{4}{*}{$\begin{array}{c}\text { Parameters optimal } \\
\text { value }\end{array}$} \\
\hline Soil & Streams Delineation & Configuring user tables & Model Calibration & \\
\hline $\begin{array}{c}\text { Location of } \\
\text { Weather stations }\end{array}$ & HRUs Definition & & Model Validation & \\
\hline $\begin{array}{c}\text { Weather Time } \\
\text { series }\end{array}$ & & & & \\
\hline
\end{tabular}

Figure 2. Components and input/output data of SWAT model. 
databases. The aim is to set up and run the SWAT model on Bouregreg catchment with the existing multisource data to illustrate the possibility and the adaptability of the model to simulate the functioning of large-scale semiarid watersheds in Morocco. The main sets of data used are briefly explained below.

\section{- Digital Elevation Model (DEM)}

The DEM (Figure 3(a)) was extracted from the ASTER Global Digital Elevation Model (ASTER GDEM) witch has a spatial resolution of $30 \mathrm{~m}$.

The DEM was used to delineate the watershed and sub-basins as the drainage surfaces, stream network and longest reaches. The topographic parameters such as terrain slope, channel slope or reach length were also derived from the DEM.

\section{- Land Use}

The land use map (Figure 3(b)) was extracted through the processing of satellite Landsat image TM that has a spatial resolution of $30 \mathrm{~m}$. The supervised classification and the photo-interpretation techniques were used to derive and distinguish the most present land use classes in Bouregreg basin.

Six major classes are so identified. The dominant categories are pasture (46\%), forest (28\%) and agriculture (24\%). The urbanized areas represent just $1 \%$ of the watershed.

\section{- Soil Data}

The soil map (Figure 3(c)) was obtained mainly from the Harmonized World Soil Database (HWSD v1.1) developed by the Food and Agriculture Organization of the United Nations (FAO-UN) [11]. This Database provides data for 16,000 different soil mapping units containing two layers (0 - $30 \mathrm{~cm}$ and $30-100 \mathrm{~cm}$ depth). Seven soil units are then extracted and completed by additional information from literature and national soil documents.

\section{- Weather Data}

The Bouregreg watershed includes several hydrometric stations that measure daily precipitation and daily river discharge. The observation data of 9 rain gages and 8 stream flow gages were collected from the Moroccan General Hydraulic Direction (Figure 3(d)).

For the temperature data, there is no station inside or near the basin that gives the daily minimum and maximum temperature for the period studied (1985-2005). In order to overcome this problem, we preferred using the global data of the UK Climate Research Unit (CRU) (http://badc.nerc.ac.uk/browse/badc/cru/data/cru_ts_3.10) that gives monthly maximum and minimum temperatures over grid of $0.25^{\circ}$ spatial resolution from 1901 to 2010 . Bouregreg watershed contains 5 points of CRU grid (Figure 3(d)) from which we had calculated necessary statistics that we had integrated in WXGEN weather generator model [12] coupled with SWAT model to generate the daily maximum and minimum temperatures from monthly data.

The use of these global temperature data was motivated by the following arguments:

- In this study, the targeted time step is the monthly period.

- The available observed temperature data covers just few years (3 to 5 years).

- The use of CRU Data was satisfactory tested in many studies in Africa involving the use of SWAT model [13].

- The comparison of available observed data in the two nearest temperature gages to Bouregreg watershed (Rabat and Meknes) and the CRU data of the nearest points to these stations shows a very good correlation with coefficient of determination $\left(R^{2}\right)$ superior to 0.90 (Figure 4).

\subsection{Model Setup}

Hydrologic modeling of Bouregreg basin was carried out using the ArcSWAT interface for SWAT2005 [14]. The model was set up using the threshold of $300 \mathrm{~km}^{2}$ as drainage area for delineating the watershed. This resulted in subdivision of the watershed into 20 sub-basins (Figure 5). Thereafter, the 467 HRUs generated firstly by combination of sub-basins, land use, soil and slope layers were generalized based on dominant land use, soil, and slope using respectively 5\%, $10 \%$ and $10 \%$ as thresholds. The urban and water classes were exempted from this simplification due to their low areas. This process had generated finally 250 HRUs that were used as the basic hydrological units for this study.

The water balance parameters were calculated using the curve number method [15] for the surface runoff and the Hargreaves method [16] for the potential evapotranspiration.

The hydrology simulation by SWAT is based on more than 26 parameters that have to be calibrated and adjusted. In such case, the calibration process becomes complex and computationally extensive [17]. The sensitivity analysis is so used to identify and rank the parameters that have significant impact on specific model output (flow in this case) [18].

The sensitivity analysis method used in ArcSWAT interface combines the Latin Hypercube simulation and the One-factor-At-a-Time sampling [19].

The calibration step aims to determine the optimal values for the parameters specified by the user. This process can be done manually or automatically based on defined optimization algorithm.

The auto-calibration option provides a powerful, labor-saving tool that can be used to reduce the frustration 


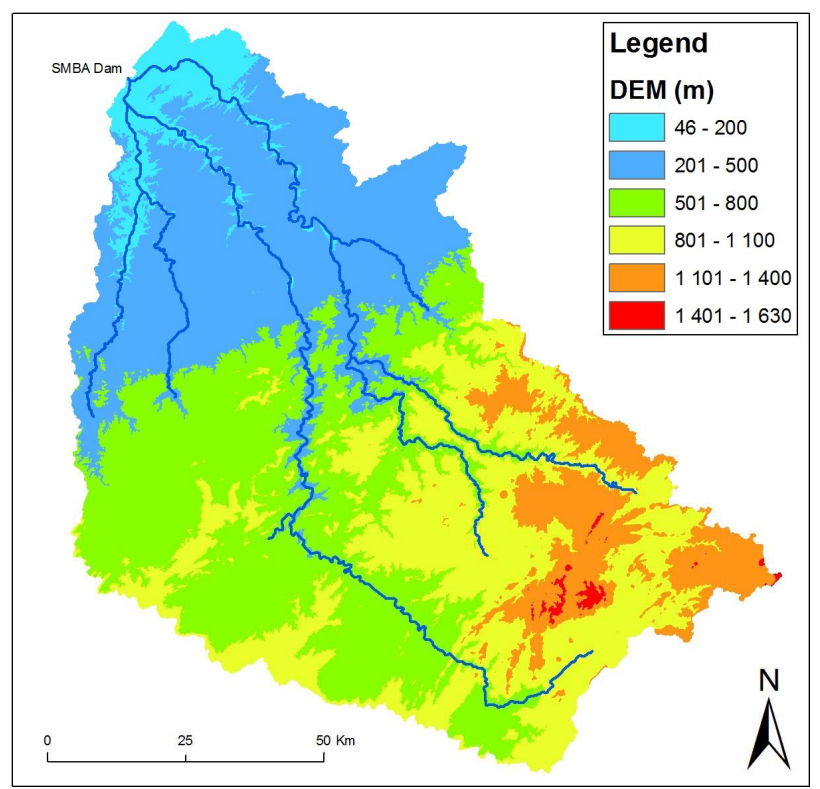

(a)

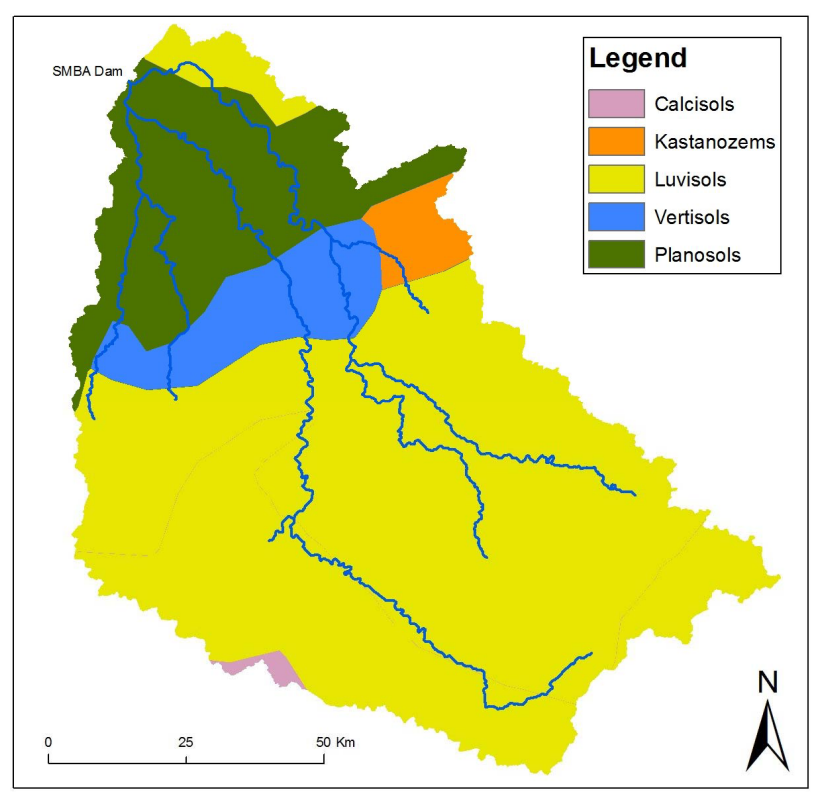

(c)

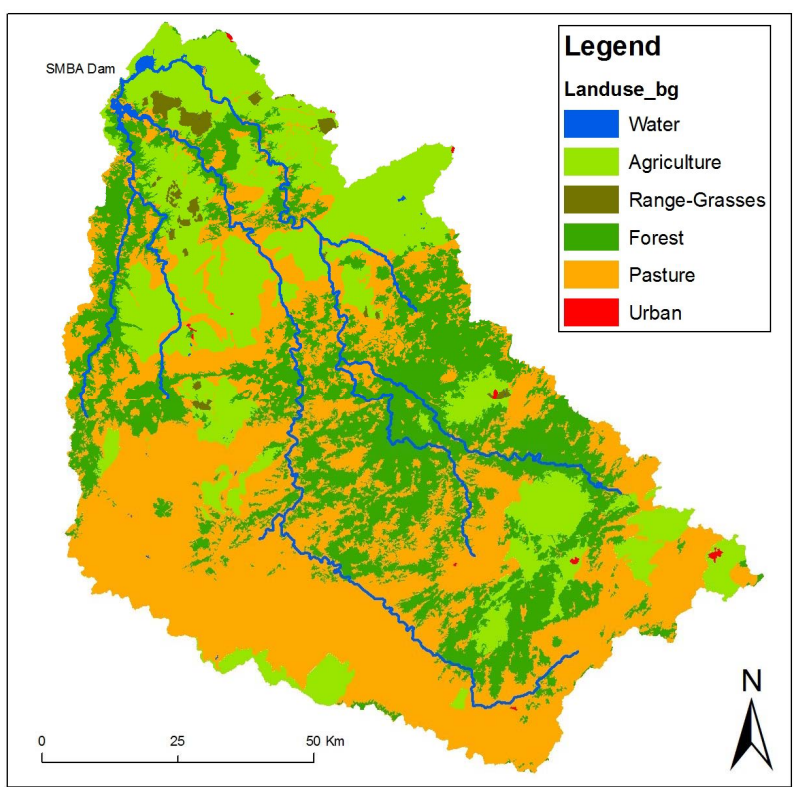

(b)

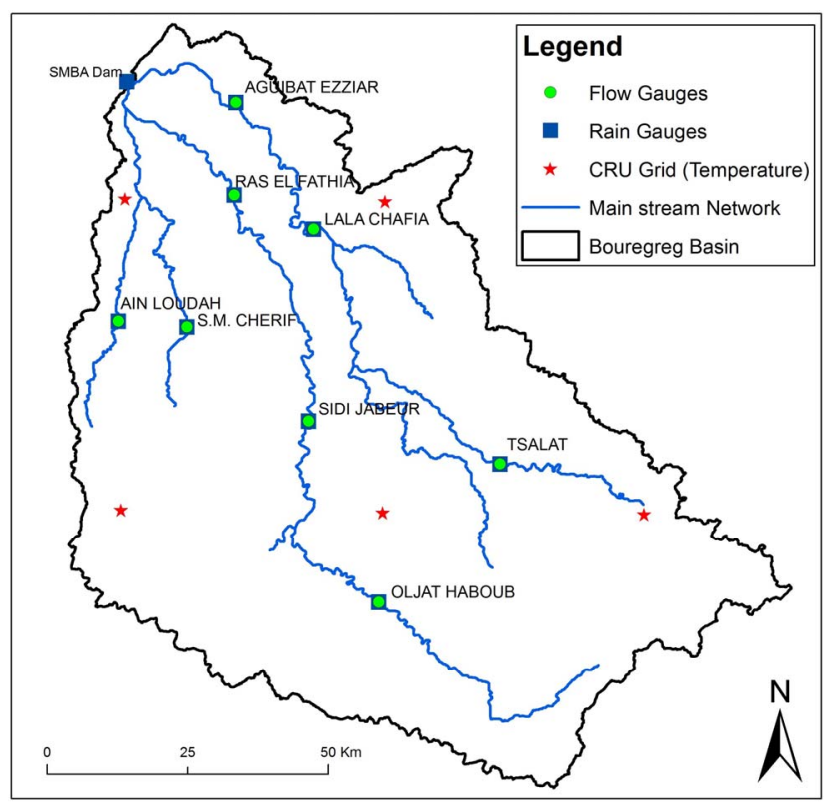

(d)

Figure 3. Basic spatial and weather data input. (a) Digital Elevation Model (DEM); (b) Land use map; (c) Soil map; (d) Location of Weather stations.

and uncertainty that often characterize manual calibration [20]. The procedure is based on optimization algorithm that tries to minimize an objective function that expresses the deviation between a measured and a simulated stream flow series.

ArcSWAT Interface offers two optimization methods for the auto-calibration process: the Generalized Likelihood Uncertainty Estimation (GLUE) [21] and the Pa- rameter Solution (ParaSol) [22]. The calibration procedure used here is the Parasol method based on a Shuffled Complex Evolution Algorithm (SCE-UA). SCE-UA has been used widely in watershed model calibration and it was generally found to be robust, effective and efficient [23]. The SCE-UA has also been applied with success to calibrate SWAT model in several studies [24].

The calibration was carried out using the average mon- 

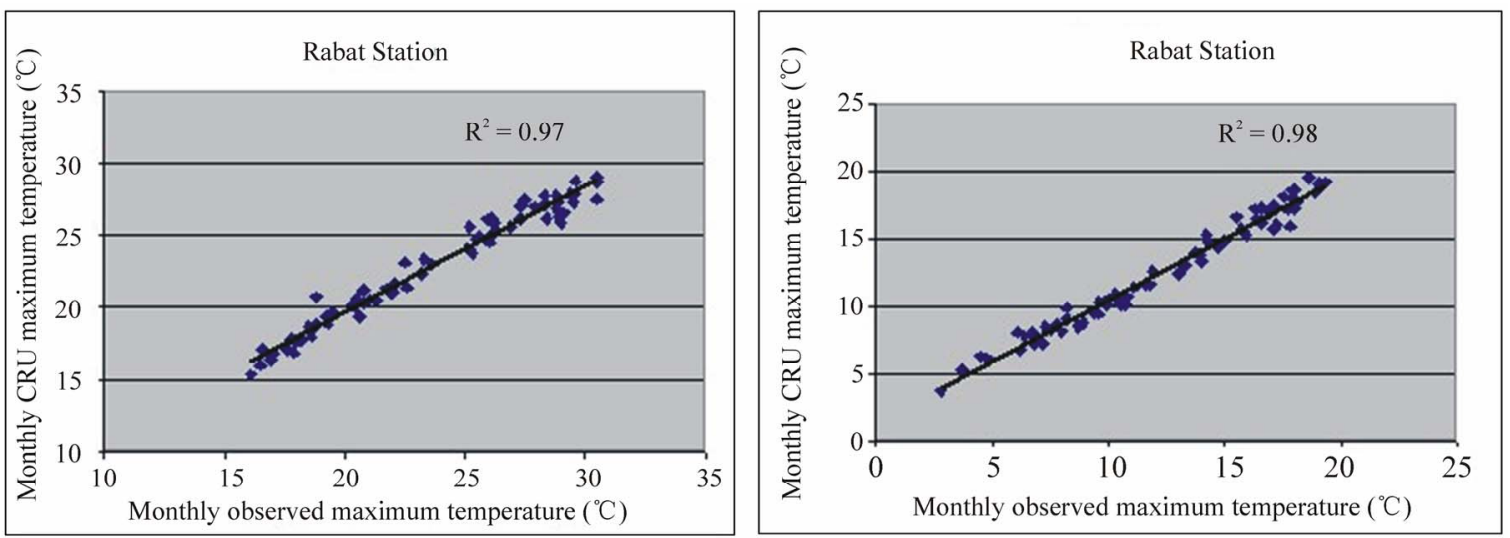

Figure 4. Observed monthly minimum and maximum temperature vs CRU Data at Rabat Station.

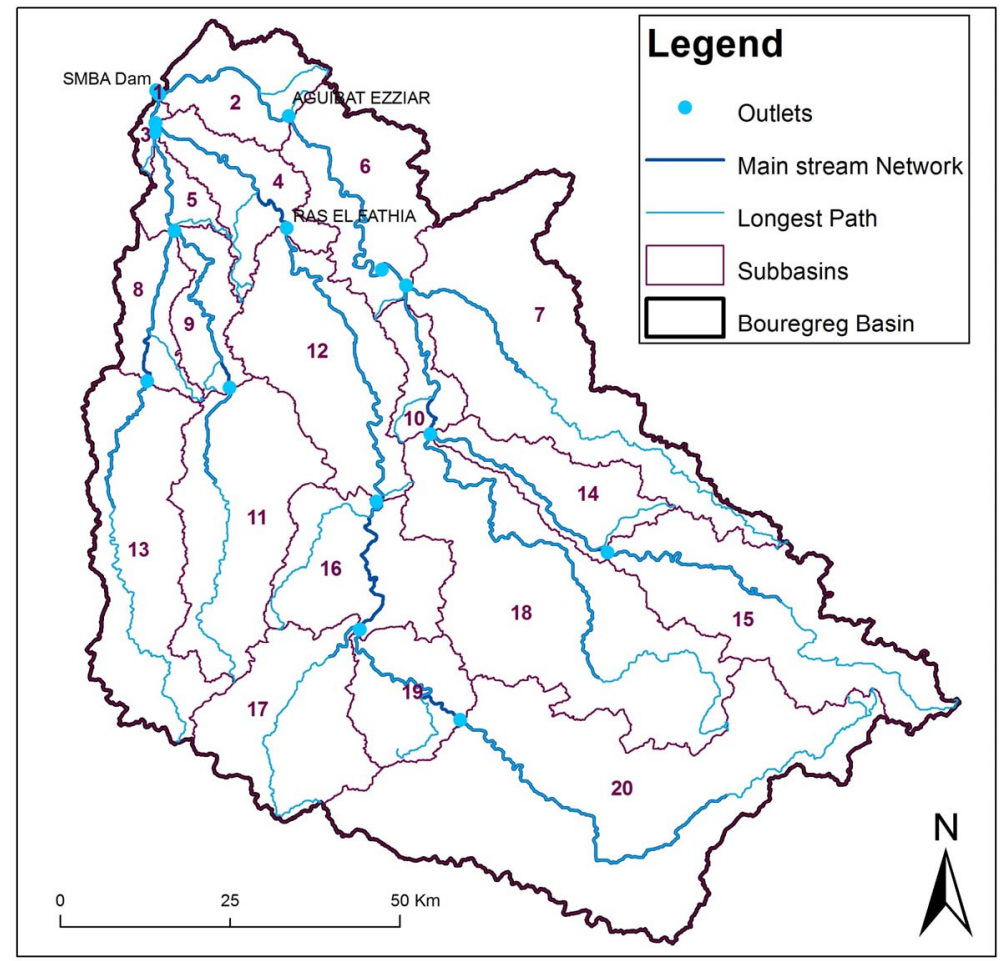

Figure 5. Delineation of sub-basins of Bouregreg watershed.

thly observed flow at the hydrometric station of Ras El Fathia.

The validation has be done thereafter to evaluate the performance of the model with calibrated parameters to simulate the hydrological functioning of the watershed over an other time period that has not been used in the calibration phase.

The validation was carried out using the coefficient of Determination $\left(R^{2}\right)$ and three statistic coefficients recommended by Moriasi [25]. These statistic operators are Nash-Sutcliffe efficiency coefficient (NSE) [26], Percent bias (PBIAS) [27], and RMSE-observations standard deviation ratio (RSR) [28]. The formulas of these coefficients are given in the following equations.

$$
\begin{aligned}
& N S E=1-\left[\frac{\sum_{i=1}^{n}\left(Y_{i}^{\text {obs }}-Y_{i}^{\text {sim }}\right)^{2}}{\sum_{i=1}^{n}\left(Y_{i}^{\text {obs }}-Y^{\text {mean }}\right)^{2}}\right] \\
& \text { PBIAS }=\left[\frac{\sum_{i=1}^{n}\left(Y_{i}^{\text {obs }}-Y_{i}^{\text {sim }}\right) * 100}{\sum_{i=1}^{n}\left(Y_{i}^{\text {obs }}\right)}\right]
\end{aligned}
$$




$$
R S R=\frac{\sqrt{\sum_{i=1}^{n}\left(Y_{i}^{\text {obs }}-Y_{i}^{\text {sim }}\right)^{2}}}{\sqrt{\sum_{i=1}^{n}\left(Y_{i}^{\text {obs }}-Y^{\text {mean }}\right)^{2}}}
$$

where $Y_{i}^{\text {obs }}$ is the $i$ th observation (streamflow), $Y_{i}^{\text {sim }}$ is the $i$ th simulated value, $Y^{\text {mean }}$ is the mean of observed data and $n$ is the total number of observations.

The temporal daily data used to set up the SWAT model in Bouregreg watershed cover 21 years (19852005). The four first years were used to initialize the model (Warm-up period). Thereafter, the parameters were calibrated from 1989 to 1997 and validated from 1998 to 2005.

\section{Results and Discussion}

\subsection{Model Calibration and Validation}

The sensitivity analysis based on surface runoff showed that the most sensitive parameters for hydrology modeling of Bouregreg basin are CN2, SOL_AWC and ESCO. This result supports those found by many similar studies confirming that these three parameters are the crucial sensitive parameters for water balance [29]. In total, 14 parameters were selected to be calibrated through the Parasol optimization method. Defining the optimal values of model variables automatically is time consuming but it was proven more efficient and reliable than the manual procedure. The rank, range and optimal values of calibrated parameters are given in Table 1.

Running SWAT model with the specified optimal values allow measuring the performance of the model. This is done by comparing the observed and simulated streamflow at the Ras El Fathia gage for both the calibration and validation periods. This comparison is summarized in Table 2 with the mentioned statistic coefficients and showed graphically in Figure 6 for calibration and Figure 7 for validation period.

The statistic evaluators showed a good correlation between the monthly observed and simulated river discharge with $R^{2}$ of 0.81 , NSE of 0.80 , PBIAS of -1.01 and RSR of 0.44 for the calibration period. The validation period revealed good values for $R^{2}(0.89)$, NSE (0.85) and RSR (0.38) but less accurate value for PBIAS (8.69). According to [25], this model performance for both calibration and validation periods is evaluated as "very good performance rating" which is defined by the flowing ranges: 0 to 0.5 for RSR, 0.75 to 1 for NSE and -10 to 10 for PBIAS.

The values of PBIAS indicate that the model had slightly overestimated the stream flow during the calibration period and had underestimated it for the validation period especially for 1999 and 2001. In the other hand, the lower value of RSR indicates the lower of the root mean square error normalized by the observations standard deviation witch indicates the rightness of the model simulation.

Figure 6 and Figure 7 show also that the peaks po-

Table 1. Rank and optimals value of calibrated SWAT parameters.

\begin{tabular}{|c|c|c|c|c|c|c|}
\hline Rank & Parameter & Parameter Name & Lower bound & Upper bound & Optimal value ${ }^{\mathbf{a}}$ & Imet $^{t}$ \\
\hline 1 & $\mathrm{Cn} 2$ & Moisture condition II curve number & -25 & 25 & 22.10 & 3 \\
\hline 2 & Esco & Soil evaporation compensation factor & 0 & 1 & 0.85 & 1 \\
\hline 3 & Sol_Awc & Available water capacity of the soil layer & -25 & 25 & 15.12 & 3 \\
\hline 4 & Sol_Z & Depth from soil surface to bottom of layer & -25 & 25 & -22.5 & 3 \\
\hline 5 & Gwqmn & Threshold water level in shallow aquifer for base flow & -1000 & 1000 & -262.14 & 2 \\
\hline 6 & Slope & Slope & -25 & 25 & 5.86 & 3 \\
\hline 7 & Sol_K & Saturated hydraulic conductivity of first layer & -25 & 25 & 6.65 & 3 \\
\hline 8 & Revapmn & Threshold water level in shallow aquifer for revap & -100 & 100 & -71 & 2 \\
\hline 9 & Blai & Potential maximum leaf area index for the plant & 0 & 1 & 0.14 & 1 \\
\hline 10 & Alpha_Bf & Baseflow alpha factor & 0 & 1 & 0.84 & 1 \\
\hline 11 & Canmx & Maximum canopy storage & 0 & 10 & 3.89 & 1 \\
\hline 12 & Epco & Plant uptake compensation factor & 0 & 1 & 0.93 & 1 \\
\hline 13 & Ch_K2 & Effective hydraulic conductivity of main channel & 0 & 150 & 0.12 & 1 \\
\hline 14 & Surlag & Surface runoff lag coefficient & 0 & 10 & 8.16 & 1 \\
\hline
\end{tabular}

a. Optimal value given by model calibration. b. Imet means variation methods available in auto-calibration procedure (1: Replacement of initial parameter by value, 2: Adding value to initial parameter, 3: Multiplying initial parameter by value in pourcentage). 


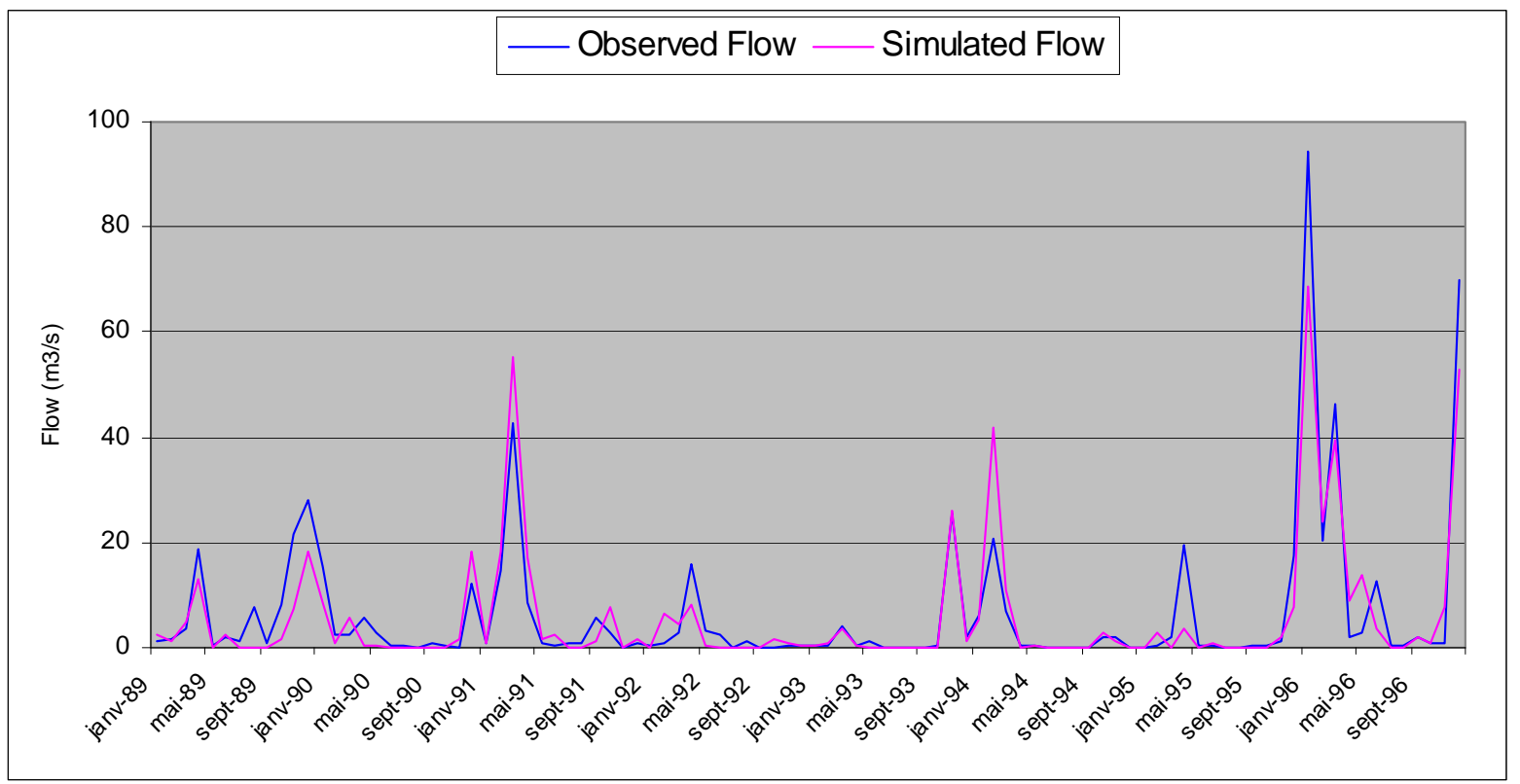

Figure 6. Comparison of monthly observed and simulated flowstream for the calibration period (1989-1997).

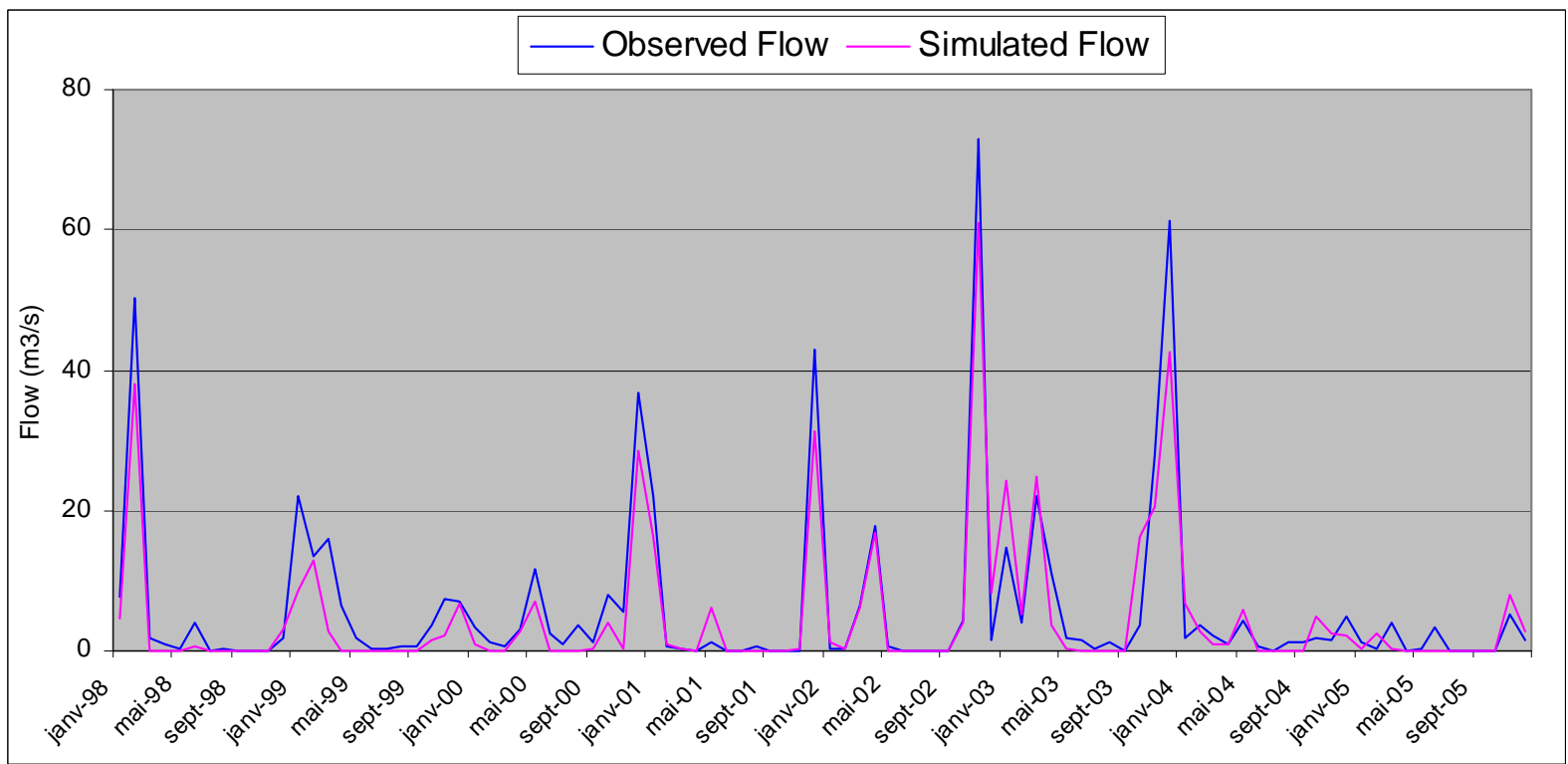

Figure 7. Comparison of monthly observed and simulated flowstream for the validation period (1998-2005).

Table 2. Statistic evaluation of simulated versus observed streamflow data.

\begin{tabular}{ccc}
\hline Coefficient & Calibration Period & Validation Period \\
\hline $\mathrm{R}^{2}$ & 0.81 & 0.89 \\
NSE & 0.80 & 0.85 \\
PBIAS & -1.01 & 8.69 \\
RSR & 0.44 & 0.38 \\
\hline
\end{tabular}

sition was generally well respected and depicted for both calibration and validation periods.

\subsection{Water Balance Components}

SWAT model calculates the water balance for each HRU considering the components mentioned in Equation 1. HRU is so the basic spatial unit where the water balance features are estimated. They can be thereafter aggregated for sub-basin and for the whole watershed.

The average yearly water balance simulated by the 
model is reported in Table $\mathbf{3}$ for both calibration and validation period.

The average difference between the observed and simulated annual total flow is $2 \%$ witch confirms a good model calibration for the monthly time step.

The ratio of the simulated average annual evapotranspiration to average annual precipitation ranges from 0.7 to 0.82 . The comparison of these ratios with the usually reported ranges reveals that the model had overestimated the evapotranspiration component. The main element suspected here can be the Hargreaves method used to calculate the potential evapotranspiration that involves just the temperature parameter estimated itself based on the global data of the CRU. In the other hand, the ratio of the simulated average annual surface runoff to average annual precipitation varies between 0.14 and 0.2 which indicates that this component is slightly underestimated.

\subsection{Estimation of SMBA Dam Inflow}

As mentioned above, one of the main objectives of this study is estimating the monthly inflow to SMBA dam in order to help the dam managers to plan and handle this import reservoir.

The monthly SMBA dam inflow was estimated with SWAT model based on the river discharge routed downstream to the whole watershed outlet. These simulated values were then compared with measured inflow as shown in Figure 8 and Figure 9 for calibration and validation periods.

The results obtained showed a good correlation between the two patterns with $\mathrm{R}^{2}$ of 0.92 for the calibration period and $\mathrm{R}^{2}$ for the validation period. Therefore, the calibrated model can be used successfully to predict the volume inflow to the SMBA dam and facilitate the storage and release water management.

\section{Conclusions}

In conclusion, SWAT model was successfully calibrated in the Bouregreg watershed. The model produced good simulation results for monthly average stream flow as for the other water balance components. The optimization algorithms integrated into ArcSWAT

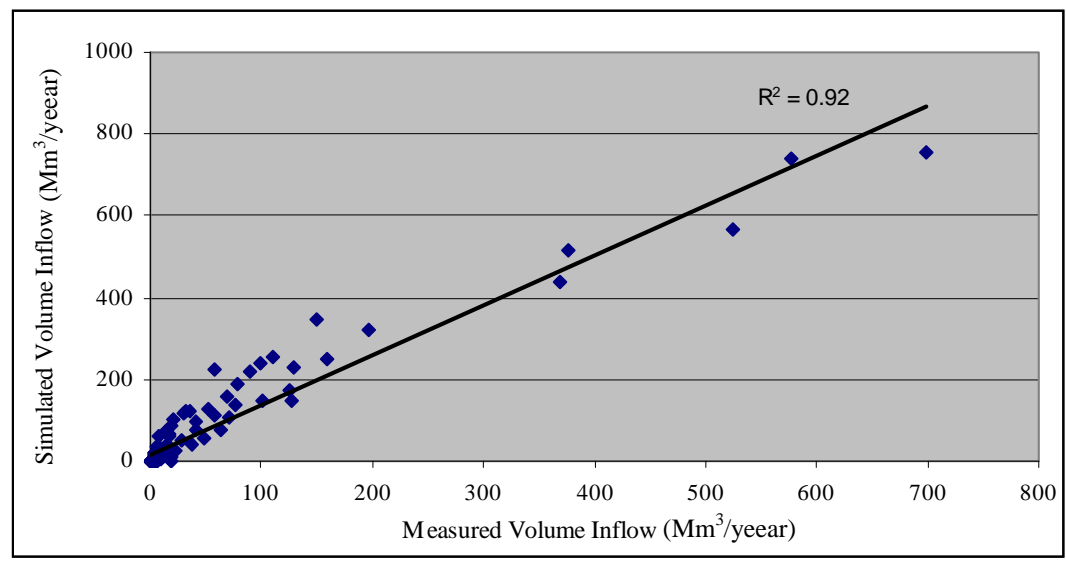

Figure 8. Comparison of monthly observed and simulated dam inflow for the calibration period.

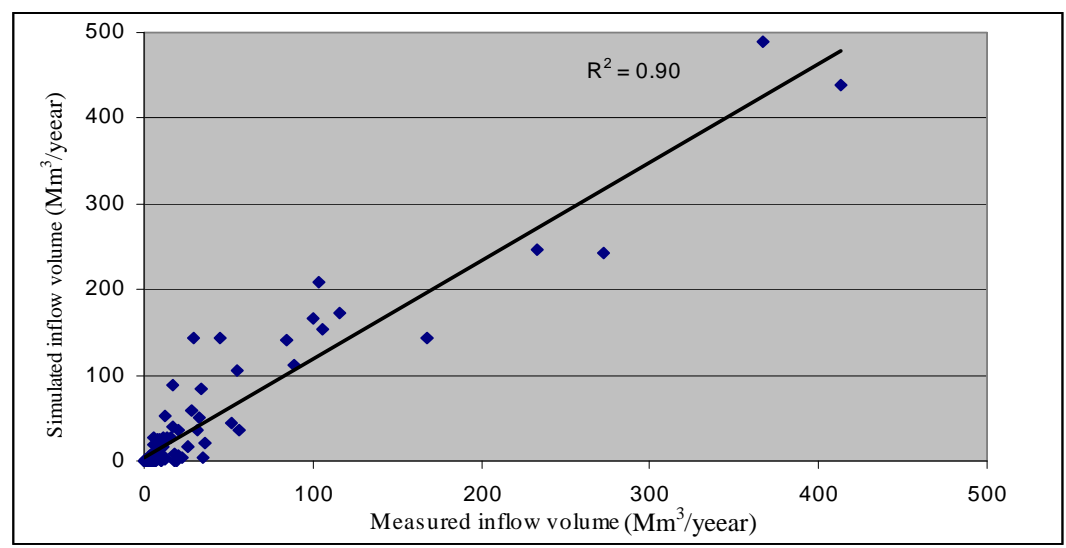

Figure 9. Comparison of monthly observed and simulated dam inflow for the validation period. 
Table 3. Yearly Average simulated water balance.

\begin{tabular}{ccc}
\hline Water balance component & $\begin{array}{c}\text { Calibration } \\
\text { Period (89-97) }\end{array}$ & $\begin{array}{c}\text { Validation } \\
\text { Period (98-05) }\end{array}$ \\
\hline $\begin{array}{c}\text { Precipitation (mm) } \\
\text { Potential Evapotranspira- } \\
\text { tion (mm) }\end{array}$ & 392 & 293 \\
$\begin{array}{c}\text { Actual Evapotranspiration } \\
(\mathrm{mm})\end{array}$ & 273 & 427 \\
Surface Runoff (mm) & 71 & 238 \\
Soil Water (mm) & 71 & 41 \\
Lateral Flow (mm) & 10 & 76 \\
Base Flow (mm) & 45 & 7 \\
\hline
\end{tabular}

interface were usefully used to calibrate the model. Hence, the optimal values of the model parameters for handling water quantities were explicitly specified and mentioned. The evaluation of the model performance was carried out successfully with the recommended statistical coefficients. In this context, the comparison of observed and simulated flowstream revealed a Nash-Sutcliffe coefficient and $R^{2}$ superior to 0.8 for both calibration and validation periods. These performances can be enhanced furthermore using more accurate input data especially for the soil and temperature features that were estimated in this study with global data. The integration of some other climatic data such as solar radiation, humidity and wind can also improve the accuracy of the evapotranspiration estimation and therefore the other water balance components.

This study had demonstrated the utility of the remote sensing and GIS to create combine and generate the necessary data to set up and run the hydrological models especially for those distributed and continuous. It had also showed the ability of SWAT model to be used to simulate the water quantity in semi-arid regions.

Thereafter, the calibrated model can be well used in Bouregreg watershed to assess and handle other watershed components such as the analysis of the impacts of land and climate changes on the water resources as well as the water quality and the sediment yield.

\section{References}

[1] M. Sivapalan, "Process Complexity at Hillslope Scale, Process Simplicity at the Watershed Scale: Is There a Connection?” Hydrological Processes, Vol. 17, No. 5, 2003, pp. 1037-1041. doi:10.1002/hyp.5109

[2] V. P. Singh and D. A. Woolhiser, "Mathematical Modeling of Watershed Hydrology," Journal of Hydrologic Engineering, Vol. 7, No. 4, 2002, pp. 270-292. doi:10.1061/(ASCE)1084-0699(2002)7:4(270)

[3] K. C. Abbaspour, "SWAT-CUP2: SWAT Calibration and Uncertainty Programs-A User Manual,” Department of
Systems Analysis, Swiss Federal Institute of Aquatic Science and Technology, Dübendorf, 2008.

[4] J. Schuol, K. C. Abbaspour, R. Srinivasan and H. Yang, "Modelling Blue and Green Water Availability in Africa at Monthly Intervals and Subbasin Level," Water Resources Research, Vol. 44, 2008, pp. 1-18.

[5] G. S. Shimelis, R. Srinivasan and B. Dargahi, "Hydrological Modelling in the Lake Tana Basin, Ethiopia Using SWAT Model,” The Open Hydrology Journal, Vol. 2, No. 1, 2008, pp. 49-62. doi:10.2174/1874378100802010049

[6] B. B. Ashagre, "SWAT to Identify Watershed Management Options: Anjeni Watershed, Blue Nile Basin, Ethiopia," Master's Thesis, Cornell University, New York, 2009.

[7] A. Chaponnière, G. Boulet, A. Chehbouni and M. Aresmouk, "Understanding Hydrological Processes with Scarce Data in a Mountain Environment," Hydrological Processes, Vol. 22, No. 12, 2008, pp. 1908-1921. doi:10.1002/hyp.6775

[8] J. G. Arnold, R. Srinivasan, R. S. Muttiah and J. R. Williams, "Large Area Hydrologic Modelling and Assessment. Part I: Model Development," Journal of the American Water Resources Association, Vol. 34, No. 1, 1998, pp. 73-89. doi:10.1111/j.1752-1688.1998.tb05961.x

[9] F. L. Ogden, J. Garbrecht, P. A. DeBarry and L. E. Johnson, "GIS and Distributed Watershed Models, II: Modules, Interfaces, and Models,” Journal of Hydraulic Engineering, Vol. 6, No. 6, 2001, pp. 515-523. doi:10.1061/(ASCE)1084-0699(2001)6:6(515)

[10] S. L. Neitsch, J. G. Arnold, J. R. Kiniry, J. R. Williams and K. W. King, "Soil and Water Assessment Tool Theoretical Documentation-Version 2005," Soil and Water Research Laboratory, Agricultural Research Service, US Department of Agriculture, Temple, 2005.

[11] F. Nachtergaele, H. V. Velthuizen and L. Verelst. "Harmonized World Soil Database (HWSD)," Food and Agriculture Organization of the United Nations, Rome, 2009.

[12] A. N. Sharpley and J. R. Williams. "EPIC-Erosion Productivity Impact Calculator, Model Documentation,” US Department of Agriculture, Agricultural Research Service, Technical Bulletin, No. 1768, 1990.

[13] J. Schuol and K. C. Abbaspour, "Using Monthly Weather Statistics to Generate Daily Data in a SWAT Model Application to West Africa," Ecological Modelling, Vol. 201, No. 3-4, 2007, pp. 301-311. doi:10.1016/j.ecolmodel.2006.09.028

[14] M. Winchell, R. Srinivasan, M. Di Luzio and J. Arnold, “ArcSWAT 2.3.4 Interface for SWAT2005: User's Guide, Version September 2009,” Texas Agricultural Experiment Station and Agricultural Research Service- US Department of Agriculture, Temple, 2009.

[15] D. C. Garen and D. S. Moore, "Curve Number Hydrology in Water Quality Modeling: Uses, Abuses, and Future Directions," Journal of the American Water Resources Association, Vol. 41, No. 2, 2005, pp. 377-388. doi:10.1111/j.1752-1688.2005.tb03742.x 
[16] G. Hargreaves and Z. A. Samani, "Reference Crop Evapotranspiration from Temperature," Applied Engineering in Agriculture, Vol. 1, No. 2, 1985, pp. 96-99.

[17] R. Rosso, A. Peano, I. Becchi and G. A. Bemporad, “An Introduction to Spatially Distributed Modelling of Basin Response,” Water Resources Publications, Highland Ranch, 1994, pp. 3-30.

[18] A. Saltelli, E. M. Scott, K. Chan and S. Marian, "Sensitivity Analysis,” John Wiley \& Sons Ltd., Chichester, 2000.

[19] A. Van Griensven and W. Bauwens, "Multi-objective Auto-calibration for Semi-distributed Water Quality Models,” Water Resources Research, Vol. 39, No. 12, 2003.

[20] M. W. Van Liew, J. G. Arnold and D. D. Bosch, "Problems and Potential of Autocalibrating a Hydrologic Model," Transactions of the ASAE, Vol. 48, No. 3, 2005, pp. 1025-1040.

[21] K. Beven and A. Binley, "The Future of Distributed Models-Model Calibration and Uncertainty Prediction," Hydrological Processes, Vol. 6, No. 3, 1992, pp. 279298. doi:10.1002/hyp.3360060305

[22] A. Van Griensven and T. Meixner, "Methods to Quantify and Identify the Sources of Uncertainty for River Basin Water Quality Models,” Water Science and Technology, Vol. 53, No. 1, 2006, pp. 51-59. doi:10.2166/wst.2006.007

[23] Q. D. Duan, "Global Optimization for Watershed Model Calibration,” Water Science Applied Series, Vol. 6, 2003, pp. 89-104. doi:10.1029/WS006p0089
[24] K. Eckhardt and J. G. Arnold, "Automatic Calibration of a Distributed Catchment Model,” Journal of Hydrology, Vol. 251, No. 1-2, 2001, pp. 103-109. doi:10.1016/S0022-1694(01)00429-2

[25] D. Moriasi, J. G. Arnold, M. W. Van Liew, R. L. Bingner, R. D. Harmel and T. L. Veith, "Model Evaluation Guidelines for Systematic Quantification of Accuracy in Watershed Simulations," Transactions of the ASABE, Vol. 50, No. 3, 2007, pp. 885-900.

[26] J. E. Nash and J. V. Sutcliffe, "River Flow Forecasting through Conceptual Models, Discussion of Principles," Journal of Hydrology, Vol. 10, No. 3, 1970, pp. 282-290. doi:10.1016/0022-1694(70)90255-6

[27] H. V. Gupta, S. Sorooshian and P. O. Yapo, "Status of Automatic Calibration for Hydrologic Models: Comparison with Multilevel Expert Calibration,” Journal of $\mathrm{Hy}$ drologic Engineering, Vol. 4, No. 2, 1999, pp. 135-143. doi:10.1061/(ASCE)1084-0699(1999)4:2(135)

[28] J. Singh, H. V. Knapp and M. Demissie, "Hydrologic Modeling of the Iroquois River Watershed Using HSPF and SWAT," Journal of the American Water Resources Association, Vol. 41, No. 2, 2004, pp. 343-360. doi:10.1111/j.1752-1688.2005.tb03740.x

[29] K. L. White and I. Chaubey, "Sensitivity Analysis, Calibration, and Validations for a Multisite and Multivariable SWAT Model," Journal of the American Water Resources Association, Vol. 41, No. 5, 2005, pp. 1077-1089. doi:10.1111/j.1752-1688.2005.tb03786.x 